\title{
Temporary Appointment Power of the President
}

On January 1, 1973, President Richard M. Nixon designated Howard Phillips Acting Director of the Office of Economic Opportunity (OEO). ${ }^{1}$ Congress and the President were at odds at that time over the future of the agency; the President planned to dismantle $\mathrm{OEO},{ }^{2}$ but the Congress had directed its continuation and appropriated funds for this purpose. ${ }^{3}$ By denominating Phillips "Acting Director" the President sought to circumvent the advice and consent process in the Senate $^{4}$ and to frustrate the congressional intent to continue $O E O,{ }^{5}$ for the President's appointee immediately began to dismantle OEO. ${ }^{6}$ Several members of the Senate ${ }^{7}$ brought suit, based on the fact that Phillips's designation had not been approved by the Senate, seeking a declaration that Phillips was illegally in office and an injunction preventing him from acting as Director. The court granted this relief and held that such appointments are unconstitutional, except when there is legislation giving the President a power to make appointments without the confirmation of the Senate or when the appointment is made during a Senate recess. ${ }^{8}$

19 Weekly Compilation of Pres. Doc. 122 (1973).

2 President Nixon, in submitting his budget message to Congress two days earlier, had not requested any appropriations for OEO. According to the President the "continued existence of OEO as a separate Federal Agency was no longer necessary." BUDGET OF THE United States Government Fiscal YeAr 1974, at 122 (1973).

3 Pub. L. No. 92-424 (Sept. 19, 1972), 86 Stat. 688.

4 U.S. Consr. art. II, \& 2. This requirement also appears in the Office of Economic Opportunity Act. 42 U.S.C. § 2941(a) (1970).

5 More recently, the President created a situation in which he used the third man in the line of succession at the Justice Department to fire Archibald Cox, the Special Watergate Prosecutor. N.Y. Times, Oct. 21, 1973, § 1, col. 8, at 1. The President here used the appointment of an Acting Attorney General to circumvent the promise that Congress had obtained from the Attorney General, as a condition of his confirmation, that the Special Prosecutor would not be unduly interfered with. The initial temporary appointment of the Acting Attorney General was clearly authorized by 28 U.S.C. $\S 508$ (1970), see note 42 infra; but his authority might be limited to thirty days by the Vacancy Act, 5 U.S.C. $\$ 3348$ (1970). A suit based on this thirty-day limitation has been filed against Acting Attorney General Bork. Proxmire v. Bork, Civ. No. 2148-73 (D.D.C., filed Dec. 6, 1973). The Justice Department, however, has contended that 28 U.S.C. § 508 (1970) exempts Bork from the thirty day limit. N.Y. Times, Nov. 24, 1973, col. 4, at 14.

6 OEO Instruction No. 6730-3 (March 15, 1973), discussed in Local 2677 v. Phillips, 358 F. Supp. 60, 66 (D.D.C. 1973).

7 Senators Harrison A. Williams, Jr., Claiborne Pell, Walter F. Mondale, and William D. Hathaway.

8 Williams v. Phillips, 360 F. Supp. 1363, 1367-68 (D.D.C. 1973). The court of appeals 
This comment considers the power of the President to make appointments without confirmation, commonly called temporary appointments. ${ }^{9}$ An examination of the language and history of the relevant constitutional provisions and the interpretations of those provisions by the executive and the courts indicates that the President's authority to make such appointments exists only where created by congressional legislation and where provided by the narrow Senate recess provision of the Constitution. ${ }^{10}$ The comment then evaluates the procedures that can be used to challenge the authority of an officer holding a temporary appointment. Two direct methods of attack, ${ }^{11}$ the writ of quo warranto and the direct senatorial suit, are of limited utility, but the authority of the appointee may also be subject to indirect challenge by an employee or beneficiary of the agency. ${ }^{12}$

\section{The Temporary Appointment Power}

\section{A. The Constitutional Power}

The constitutional structure of governmental appointments is set forth in article II, section 2, which provides:

[The President] shall nominate, and by and with the Advice and Consent of the Senate, shall appoint Ambassadors, other public Ministers and Consuls, Judges of the supreme Court, and all other Officers of the United States, whose Appointments are not herein otherwise provided for, and which shall be established by Law: but the Congress may by Law vest the Appointment of such inferior Officers, as they think proper, in the President alone, in the Courts of Law, or in the Heads of Departments.

The President shall have Power to fill up all Vacancies that may

denied Phillips's motion for a stay pending appeal, because he had not shown sufficient likelihood of success on the merits. 482 F.2d 669 (D.C. Cir. 1973).

9 There are three categories of temporary appointments: first, those made during the recess of the Senate under article II, section 2, clause 3 of the Constitution, lasting only until the end of the next session of the Senate; second, those made under statutory authority, generally valid for only thirty days, see text and notes at notes 41-50 infra; third, those denominated "temporary" by the President to avoid the confirmation requirement applicable to permanent appointments, with only presidentially determined limits on their duration. The term "temporary appointment" in this comment will refer to the last category.

10 See text and notes at notes 13-40 infra. It is no longer comforting to assert, as did early Attorneys General, that a broad interpretation of the President's temporary appointment power "cannot possibly produce mischief, without imputing to the President a degree of turpitude entirely inconsistent with the character which his office implied, as well as with the high responsibility and short tenure annexed to that office." I OP. ATT'Y GEN. 681, 634 (1823).

11 See text and notes at notes 56-85 infra.

12 See text and notes at notes 86-111 infra. 
happen during the Recess of the Senate, by granting Commissions which shall expire at the end of their next session.

In this structure the President is given express authority to make appointments without the advice and consent of the Senate in only two instances-where Congress has by law given this right to the President and where a vacancy occurs while the Senate is in recess. Moreover, article II seems to exclude any implied powers of appointment, in particular any implied power to make temporary appointments to insure the smooth flow of governmental functions pending submission of a nomination to the Senate..$^{13}$ If the President had such power, the recess vacancy clause would be mere surplusage. Yet "[i]t can not be presumed, that any clause in the constitution is intended to be without effect; and therefore, such a construction is inadmissible, unless the words require it."14 The recess vacancy clause thus compels rejection of an implied temporary appointment power.

This interpretation of the appointment provisions is supported by an examination of their development in the Constitutional Convention and subsequent interpretations of the provisions by the executive branch and the courts.

1. Presidential Appointment Power in the Constitutional Convention. The initial draft of the Constitution authorized exclusive presidential appointment of all officers ${ }^{15}$ except Judges of the Supreme Court and Ambassadors, who were to be appointed by the Senate. ${ }^{16}$ The first mention of concurrent authority came on June 18 when

13 Presumably, the invocation of the article II, section 3 requirement that the President "take Care that the Laws be faithfully executed" in Williams v. Phillips, $360 \mathrm{~F}$. Supp. 1363, 1368 (D.D.C. 1973), was an argument that the President must on occasion be empowered independently to make temporary appointments to insure that there is a full complement of executive officers at all times, so as to maintain the smooth functioning of the government. The only independent temporary appointment power either considered or adopted in the Constitutional Convention, however, was that which provided for appointments made during the recess of the Senate, a period lasting a number of months. The concerns of the Convention were echoed by Hamilton, who approved the joint vesting of the appointment power in the President and the Senate, but thought it was necessary to allow a recess appointment power because a vacancy might occur that the public interest required to be filled without excessive delay. THE FEDERALIST No. 67, at 371 (A. Scott ed. 1894).

In the opinion of early Attorneys General it was the intention of the Constitution that if an office became vacant, the vacancy should not be a protracted one, that is, throughout the recess of the Senate. 1 OP. ATT'Y GEN. 631, 632 (1823). See also 2 OP. ATT'Y GeN. 525, 527 (1832). No concern was voiced, however, about the possibility of vacancies pending Senate confirmation of a nomination.

14 Marbury v. Madison, 5 U.S. (1 Cranch) 137, 173 (1803).

$151 \mathrm{M}$. Farrand, The Records of the Federal Convention of 1787, at 226 (1937).

162 M. FARRAND, supra note 15 , at 183. 
Alexander Hamilton suggested that the President have "the sole appointment of the heads or chief officers of the departments of Finance, War and Foreign Affairs; to have the nomination of all other officers (Ambassadors to foreign Nations included) subject to approbation or rejection of the Senate."17 Although Hamilton's proposal was not seriously considered at that time, the Committee of Eleven's September 4th report suggested that the President should appoint all officers of the government, including Supreme Court Judges and Ambassadors "by and with the advise and consent of the Senate."1s

The recess appointment clause was added on September 7, three days after it was decided that the President's appointment power was to be exercised with the advice and consent of the Senate. ${ }^{19}$ Once the President's power was so limited, there was a need to provide for appointments during the extended periods in which the Senate would not be in session. There was no concern expressed, however, over the possibility that an office might remain vacant for a short period while the Senate considered a nomination. The final modification of the appointment provisions came on September 15 with the acceptance of Gouverneur Morris's suggested addition: "but the Congress may by law vest the appointment of such inferior Officers as they think proper in the President alone, in the Courts of Law, or in the heads of Departments."20

The constitutional history thus shows that while the number of appointments made by the President was progressively expanded, he was in all cases required to act with the advice and consent of the Senate. ${ }^{21}$ Ultimately, the President's express independent appointment

17 I M. FARRAND, supra note 15, at 292. Concurrent authority surfaced again on July 17 with two suggested methods of appointing the judiciary. Although neither was adopted, they evidence a desire for some limit on the presidential appointment power. The first provided that any nomination be made a certain number of days before the appointment was scheduled to take effect and that the appointment would become effective if not disapproved within that time. $2 \mathrm{M}$. FARRAND, supra note 15 , at 37 . The second provided that the Chief Executive make appointments with the concurrence of at least one-third of the Senate. Id. at 42. It was suggested on August 20 that persons comprising a Council of State, including the Chief Judge of the Supreme Court and the Secretaries of Domestic Affairs, Commerce, Foreign Affairs, War, Marine, and State, be "appointed by the President during his pleasure." Id. at $342-43$.

$18 I d$. at 498-99. It was suggested in Myers v. United States, 272 U.S. 52 (1926), that the joining of the appointment power in the President and Senate after the Great Compromise was prompted by the small states' desire to reduce the possible tendency of a President chosen by the large states to appoint officers only from the large states. Id. at 111.

192 M. FARRAND, supra note 15, at 533; REPORT of THE CoMmitTeE on STYLE, in id. at 574.

$20 \mathrm{Id}$. at 627.

21 The rationale behind vesting the appointment power in the Senate and the Presi- 
power was limited to situations in which Congress has enacted specific provisions or the Senate is in recess.

2. Interpretations by the Executive Branch. Most of the legal interpretations of the appointment provisions are contained in opinions of the Attorney General. ${ }^{22}$ These opinions agree that, without express enactment to the contrary, the appointment power is vested jointly in the President and the Senate ${ }^{23}$ and that the "purpose of the Constitution is to prohibit the President from making appointments without the advice and consent of the Senate." 24 The only exception to this principle, the opinions conclude, is the recess vacancy clause, which, because of the general public interest in keeping offices filled, ${ }^{25}$ gives the President the power to make temporary appointments when the Senate has adjourned. ${ }^{26}$

Relying on four opinions of the Attorney General, one authority has suggested that the President has some implied power to make temporary appointments: "Usually a situation of this nature is provided for in advance by a statute which designates an inferior officer who is to act in place of his immediate superior, but, in lack of such a provision, theory and practice alike concede the President the power to make a designation."27 Although there is ample support for the proposition that vacancy appointments are generally provided for in ad-

dent jointly was explained by Hamilton: "[A] man who had himself the sole disposition of offices, would be governed much more by his private inclination and interests, than when he was bound to submit the propriety of his choice to the discussion and determination of a different and independent body; and that body an entire branch of the Legislature." The FederalisT No. 76, at 417 (A. Scott ed. 1894). This concession to practicality was criticized in the North Carolina ratifying convention as being a monarchical power. See IV J. Elliot, Debates on the Federal, Constitution 135 (1836).

22 Opinions of the Attorney General were approved as precedent in a recent case on recess appointments. United States v. Allocco, 305 F.2d 704, 713 (2d Cir. 1962).

23 "[T]he general rule is that, where there is no express enactment to the contrary, the appointment of any officer of the United States belongs to the President by and with the advice and consent of the Senate." 17 OP. ATT'Y GEN. 532, 533 (1883). See also 15 OP. ATt'Y GeN. 449, 450 (1878); 15 OP. ATT'Y GEN. 3, 5 (1878).

2433 OP. ATT'Y GEN. 20, 21 (1921).

25 See text and note at note 13 supra.

261 OP. ATT'Y GEN. 631, 632 (1823). The recess clause is usually read as only permitting appointments made during a recess, regardless of when the vacancy arose. See, e.g., United States v. Allocco, 305 F.2d 704 (2d Cir. 1962); 12 Op. ATT'Y GEN. 32 (1866).

27 E. Corwin, The President: Office and Powers 1787-1957, at 79 (1957). In Williams v. Phillips, 360 F. Supp. 1363, 1368 (D.D.C. 1973), the government relied on two opinions of the Attorney General. One concluded that repeal of legislation granting an appointment power to the Secretary of the Treasury returned the power to the President, subject to the advice and consent of the Senate. 18 OP. ATT'Y GEN. 98 (1885). The other reached a similar conclusion concerning a provision that did not specify who should name the Chief Examiner of the Civil Service. 18 OP. ATr'y GEN. 409 (1886). 
vance, ${ }^{28}$ none of the opinions supports the contention that where no vacancy provision exists the President has an implied temporary appointment power; ${ }^{29}$ one of the opinions ${ }^{30}$ even supports the assertion that there is no such power. That opinion, dealing with the President's authority to make a temporary recess appointment to a vacancy that exists during the Senate session, acknowledged that "whenever there is a vacancy existing during the session, whether it first occurred in the recess or after the session began, the power to fill requires the concurrent action of the President and the Senate."31 In denying the existence of any presidential authority to make an appointment during the Senate session without the advice and consent of the Senate, this opinion is consistent with the others that have been rendered on the question.

3. Judicial Interpretations. Although there is little case law on the President's article II, section 2 appointment power, those cases that have dealt with the provisions confirm the limited nature of that power. In Scully $v$. United States, ${ }^{32}$ the leading case defining which officers are covered by the provisions, the court stated:

When Congress creates an office, whether it be inferior or not, and omits to specify how the incumbent is to be appointed, it is one of that class designated in the Constitution as "all other officers of the United States whose appointments are not herein otherwise provided for"; and in such cases the appointment must be made by the President by and with the advice and consent of the Senate. ${ }^{33}$

Similarly, when Congress does not specify procedures by which a tem-

28 See text and notes at notes 41-42 infra.

20 The earliest opinion on which Corwin relied concerned appointments by a naval commander at sea, exempted by statute from the requirement of senatorial advice and consent. It was concluded that the statute empowered the President to make regulations for such appointments, but not that the President has the inherent authority to do so. 6 OP. ATT'Y GEN. 357 (1854). The second opinion simply pointed out that the President has a fundamental and constitutional right to make temporary recess appointments. 25 OP. ATT'Y GEN. 258 (1904). The third opinion interpreted a statute allowing temporary appointment to a vacancy of an officer or department head whose original appointment was confirmed by the Senate. The opinion argued that only officers in departments established by law were qualified for such appointments. 28 OP. ATT'Y GEN. 95 (1909).

Corwin also cited one nineteenth century anecdote about a temporary Presidential appointment; but one instance is scarcely enough to put a gloss on the powers of the President in the sense intended by Justice Frankfurter in his concurring opinion in Youngstown Sheet \& Tube Co. v. Sawyer, 343 U.S. 567, 611 (1952), particularly where the opinions of the Attorneys General deny the existence of such a gloss.

30 12 Or. ATT'Y GEN. 32 (1866).

31 Id. at 39.

32198 F. 185 (C.C.D. Nev. 1910).

33 Id. at 187. 
porary appointment is to be made, it must subject to Senate confirmation.

In United States $v$. Maurice, ${ }^{34}$ the first case that directly addressed the question of unconfirmed appointments, Chief Justice Marshall, sitting as a circuit judge, rejected the concept of an implied presidential power to make such appointments. In that case the President had attempted to avoid confirmation by unilaterally creating and filling an office. Marshall rejected the contention that senatorial confirmation was not required for offices created by the President under his constitutional duty to see that the laws are fairly executed. ${ }^{35}$ In rejecting an exception for presidentially created offices, Marshall held that the Senate must confirm every nonrecess presidential appointment except those specifically exempted by Congress. ${ }^{36}$

The only recent case on this question, Williams $v$. Phillips, ${ }^{37}$ held that, absent express congressional or constitutional authority, the President has no power independently to make temporary appointments. The court in Williams rejected, as had the court in Maurice, the argument that the requirement that the President "take Care that the Laws be faithfully executed" implies a power to make appointments without the advice and consent of the Senate. ${ }^{38}$

These cases clearly hold that, excepting the recess situation, the President can make unconfirmed appointments-whether denominated temporary or not-only where such power is specifically authorized by Congress. Congress has provided with thoroughness for interim appointments pending nomination and confirmation of a permanent officer. ${ }^{39}$ The very thoroughness of the scheme indicates that where the President is not specifically authorized to make unconfirmed appointments, Congress intended to deny such power. ${ }^{40}$

3426 F. Cas. 1211, 1213 (No. 15,747) (C.C.D. Va. 1823). The court here considered the validity of an appointment bond given by an officer who was appointed to an established office in an irregular manner.

$35 \mathrm{Id}$. at 1213.

36 Id.

37360 F. Supp. 1363 (D.D.C. 1973).

38 Id. at $1368-69$.

39 See text and notes at notes 41-51 infra.

40 This conclusion is directly presented in 6 OP. ATr'Y GEN. 1 (1853), which suggests that one method of determining congressional intent is to refer to analogous enactments. The analogous enactments there had given to the heads of departments the power to appoint Assistant Secretaries. In the State Department there was no such grant of the appointment power. The Attorney General concluded that the appointment of an Assistant Secretary of State could only be made by the President with the advice and consent of the Senate. Where Congress has given appointment powers to the President for so many offices, a lack of such express authorization would indicate that it desired to retain the requirement of advice and consent. 


\section{B. Statutory Temporary Appointment Power}

In various statutes Congress has established procedures to fill vacancies in offices that are subject to the advice and consent requirement. These procedures ensure that the government will continue to operate efficiently despite vacancies. The Vacancy Act ${ }^{41}$ is a general congressional provision for succession at the top of the executive and military departments ${ }^{42}$ and the bureaus within those departments. When such a vacancy occurs, the first assistant, who must have been confirmed by the Senate in all of the departments covered by the Act, is automatically authorized to perform the head officer's duties until a permanent successor is named. ${ }^{43}$ The President also has the option of naming an officer of another department or bureau, whose permanent appointment has been confirmed by the Senate, to fill the vacancy. ${ }^{44}$ In each of these cases, however, the temporary officer's authority is limited to thirty days; ${ }^{45}$ after this period has elapsed the office must remain vacant until a permanent officer is appointed with the advice and consent of the Senate. ${ }^{46}$ An officer who has served more than thirty days is presumably subject to the same legal challenges as one who is improperly in office from the start.

In addition to the Vacancy Act, Congress has enacted specific vacancy provisions for most governmental organizations. In administrative agencies $^{47}$ the Administrator, who is appointed with Senate approval, has the power to designate a deputy to act as Administrator in case of vacancy; the President also has the authority to name an "officer" of the government to act as Administrator. ${ }^{48}$ In the numerous govern-

415 U.S.C. $\S \S 3945-49$ (1970).

42 That is, the Defense, Labor, State, HEW, HUD, Interior, Commerce, Agriculture, Treasury, Transportation, and Justice Departments. 5 U.S.C. $\$ 101$ (1970). Specific lines of succession, in compliance with the Act, have been established by executive order for all of the departments except Justice, which is covered by 5 U.S.C. $\$ 508$ (1970), and Transportation, which is covered by 49 U.S.C. \& 1652 (1970). Solicitor General Bork may have become the Acting Attorney General under the statutory provision. See note 5 supra.

435 U.S.C. §§ $3345-46$ (1970).

44 Id. $\S 3347$.

45 Id. $\S 3348$.

46 With regard to an earlier ten day limit, it was said, "The statutory power being exhausted, the President is remitted to his constitutional power of appointment. No appointment has been made, and there ... can be no person authorized by designation ... ."16 Or. ATT'Y GeN. 596, 597 (1880). There is no indication that the law in this area has changed since 1880.

47 For example, the General Services Administration, 40 U.S.C. $\S 751$ (1970), and the Veterans Administration, 38 U.S.C. § 210 (1970).

48 In these instances Congress treated the position of Deputy Administrator as an "inferior" office and allowed it to be filled by the Administrator. Congress has restricted the President's range of choice in naming temporary administrators, however, to "officers," ensuring that the President's choice has previously been confirmed by the Senate. 
ment agencies ${ }^{49}$ the enabling legislation requires that both the chief and his deputy be confirmed by the Senate and provides that the deputy is authorized to act in case of a vacancy. ${ }^{50}$ Thus, in providing by statute for temporary appointments, Congress has attempted to ensure that only someone previously confirmed by the Senate can be appointed by the President to fill a vacancy. ${ }^{51}$

In Youngstown Sheet \& Tube Co. v. Sawyer, ${ }^{52}$ Justice Jackson, discussing the proper means of evaluating presidential implied powers, stated that where the President acts in a manner incompatible with the express or implied will of Congress, his powers are to be narrowly construed. ${ }^{53}$ The care with which Congress has sought to preserve its right of consent indicates that an implied presidential appointment power should be treated as incompatible with the will of Congress and permitted only in the most extreme and compelling cases. ${ }^{54}$

49 E.g., Export-Import Bank, 12 U.S.C. § 635(a) (1970); Federal Aviation Administration, 49 U.S.C. $\S \S 1341-42$ (1970); National Science Foundation, 42 U.S.C. $\$ 1864$ (1970); United States Information Agency, Reorg. Plan No. 8 of 1953, § 1, 67 Stat. 642 (1953), as amended, 69 Stat. 183 (1955).

50 Congress has also provided that vacancies within regulatory commissions do not impair the power of the remaining commissioners to continue to perform the duties of the commission. E.g., Federal Power Commission, 16 U.S.C. \$ 792 (1970); Federal Trade Commission, 15 U.S.C. § 41 (1970); Interstate Commerce Commission, 49 U.S.C. § 11 (1970). An identical provision applies to the National Labor Relations Board, 29 U.S.C. $\S 153(\mathrm{~b})$ (1970). The General Counsel of the NLRB is independently appointed by the President, but may serve only forty days unless a nomination is submitted to the Senate. 29 U.S.C. § 153(d) (1970). These provisions suggest that Congress intended that the President follow the normal appointment procedure-advice and consent-and that the orderly administration of the government's business not be interrupted in the interim.

51 A particularly clear example of the intent to preserve the senatorial confirmation power is present in the Office of Economic Opportunity Act, 42 U.S.C. $\S \S 2941$ et seq. (1970). Under the OEO Act, both the Director and Deputy Director are appointed with the advice and consent of the Senate, but the Deputy is not expressly authorized to act as Director in case of vacancy. Although Congress had granted vacancy powers to various officers of other agencies, it chose not to do so in OEO. Moreover, the provisions of the Vacancy Act do not apply, because OEO is not an executive or military department or bureau within the terms of the Vacancy Act. See note 42 supra. Even if OEO were covered by the Vacancy Act, Phillips, see text and notes at notes 1-8 supra, who had not been confirmed for his prior position, would not have been an officer the President was permitted to designate. See 5 U.S.C. § 3347 (1970). The President's appointment of Phillips to be Acting Director thus appears to have completely disregarded the intent of Congress. In the original OEO hearings, concern was expressed over the inordinate amount of power and discretion vested in the Director, See, e.g., Hearings on S. 2642 Before the Senate Comm. on Labor and Public Welfare, 88th Cong., 2d Sess., pt. 2, at 128. The Director was termed a "poverty czar." Id. at 184-85. Congress must therefore have wished to maintain all possible control over OEO by preserving the requirement of Senate confirmation for even a temporary Director.

52343 U.S. 579 (1952).

53 Id. at $637-38$ (concurring opinion).

54 For example, in wartime the President might be justified in making an interim appointment of a successor to the Secretary of Defense from within the Department of 
Accepting the views of the Constitutional Convention, Attorneys General, the courts, and Congress, the question of appropriate remedies for violation of the constitutional and statutory requirements remains. Although the only available direct sanction against the President is the last resort of impeachment, ${ }^{55}$ judicial procedures are available to challenge the authority of an officer who has been illegally appointed or who has illegally remained in office beyond the term permitted by statute.

\section{Procedures to Ghallenge Authority}

A direct challenge to the validity of a temporary presidential appointment can be brought by the Justice Department on a writ of quo warranto or by members of the Senate claiming deprivation of the constitutional right to confirm presidential appointments. Either action, if successful, results in removal of the official and an injunction against the official's further actions. ${ }^{56}$ Employees and beneficiaries of a department headed by an improperly appointed officer lack standing to bring a direct challenge to that officer's title. ${ }^{57}$ Where an officer orders some action that injures an employee or beneficiary, however, that action may be subject to attack, and one basis for relief in such a suit could be the invalidity of the appointment. ${ }^{58}$ The major obstacle to these indirect challenges is the de facto officer doctrine, ${ }^{59}$ which validates the acts of a person with a colorable claim of valid appointment. Recent judicial limitations on this doctrine may, however, make the courts more willing to consider such challenges.

\section{A. Direct Challenges}

1. Quo warranto. Title to office could be challenged at common law only by a writ of quo warranto or a writ in the nature of quo warranto;

Defense where all other interdepartment successors permitted by statute were for some reason disqualified.

55 This remedy was suggested at 2 Op. ATt'y GEN. 525, 529 (1832). See R. BERGER, IMpeachment: The Constrtutional Problems 299-300 (1973). See also E. Corwin, supra note 27 , at 75 .

58 In considering the motion for a stay in Williams, the court of appeals suggested another possibility-that the district court amend its order to allow the President time to conform to the Constitution and statutes. 482 F.2d at 671 . The district court did not adopt this course, and the appeal on the merits was not pursued.

67 The most promising possibilities for standing to bring indirect challenges lie with beneficiaries and employees. It is questionable whether mere taxpayers would have standing to challenge an official's title, either directly or indirectly, under the obscure standard of Flast v. Cohen, 392 U.S. 83 (1968).

58 The challenge might also be based on the per se illegality of the official's action, as where an official violates a plain statutory duty.

50 See text and notes at notes 99-111 infra. 
these writs could be sought only by the government on its own behalf or, in the discretion of the Attorney General and the courts, on behalf of a private individual. ${ }^{60}$ Where the writ is issued, the official is removed from office and all acts by the official after issuance of the writ are void; ${ }^{61}$ the writ cannot be used, however, to challenge specific actions performed prior to its issuance. ${ }^{62}$

Federal quo warranto actions are governed by the District of Columbia Code, ${ }^{63}$ which reflects the common law ${ }^{64}$ in severely restricting standing to bring quo warranto actions against federal officers. Under the Code, the Attorney General of the United States or the United States Attorney for the District of Columbia may, at his discretion, institute a quo warranto action in the District Court for the District of Columbia to test the legality of the title of a federal officer. ${ }^{65}$ If the Attorney General or United States Attorney declines to institute such an action after being requested by "a person interested,"66 such person may seek the writ from the court. ${ }^{67}$

Private individuals, however, do not qualify as interested persons. As the Supreme Court has observed, "the Code, not only does not authorize a private citizen, on his own motion, to attack the incumbent's title, but it throws obstacles in the way of all such private attacks." 68 The Court has held that a citizen who has no interest except that common to every other member of the public cannot petition the court to issue the writ. ${ }^{69}$ The courts generally assume that the officials empowered to obtain the writ adequately represent the public interest. ${ }^{70}$

60 These writs are incorporated into modern federal civil practice by FED. R. Crv. P. 81(a). United States v. Machado, 306 F. Supp. 995, 1000 (N.D. Cal. 1969).

61 F. Mechem, The Law of Public Offices and Offickrs § 497 (1890).

62 "Quo warranto is addressed to preventing a continued exercise of authority unlawfully asserted, not to a correction of what has already been done under it or to a vindication of private rights." Johnson v. Manhattan Ry., 289 U.S. 479, 502 (1933).

63 Perhaps in recognition of the fact that most quo warranto writs against a federal officer will be brought in the District of Columbia, the Supreme Court has held that the District of Columbia Code, $\$ \S 16-1601$ to -1604 (1961), governs all quo warranto actions against federal officers. Newman v. United States ex rel. Frizzell, 238 U.S. 537, 552 (1915).

64 See text at note 60 supra.

65 D.C. CODE ANN. $\S 16-1601$ to -1604 (1961).

66 See text and notes at notes $68-73$ infra.

67 D.C. CODE ANN. § 16-1603 (1961).

68 Newman v. United States ex rel. Frizzell, 238 U.S. 537, 546 (1915).

$69 \mathrm{Id}$. at 550 . Although the rule is the same with respect to elective offices, where the office is appointive the courts have been especially reluctant to issue the writ at the request of a private citizen. It has been said the federal courts lack "general supervising power over the appointment of federal officials and have been reluctant to impose restrictions upon the power of the President in this area." Jalil v. Hampton, 460 F.2d 923, 926 (D.C. Cir. 1972).

70 See Newman v. United States ex rel. Frizzell, 238 U.S. 537, 547 (1915). 
The Supreme Court has held that a person must have an interest in the office held by the challenged official to be a "person interested" and authorized to sue for the writ.71 Thus a Deputy Director who would normally act as Director in case of a vacancy ${ }^{72}$ would be an interested party if the President were to appoint someone else; if the President is permitted to appoint either the Deputy or another officer to fill a vacancy,73 but appoints someone who is not an officer, those persons qualified to fill the vacancy would be interested parties. It is difficult, however, to conceive of a situation in which anyone other than an "officer" would qualify as a person with an interest in the office.

Quo warranto is therefore an unsatisfactory means of challenging temporary presidential appointments, because a member of the executive branch is unlikely to bring an action that can only embarrass the President, ${ }^{74}$ and private citizens do not have the requisite interest to bring the action.

2. Senatorial Suit. The validity of a temporary presidential appointment can also be directly challenged by Senators ${ }^{75}$ claiming deprivation of their constitutional right of advice and consent to the appointment of officers of the government. Congressmen clearly have standing to challenge presidential acts that prevent Congress from fulfilling its constitutional function. In Williams $v$. Phillips, ${ }^{76}$ the court held that senators have standing to challenge temporary appointments because of their constitutional obligation to advise and consent to appointments. Similarly, in Mitchell v. Laird, ${ }^{77}$ members of the House of Representatives were held to have standing to challenge the constitutionality of the Vietnam war, because they alleged that performance of their constitutional duties as legislators had been frustrated by executive action. ${ }^{78}$

It also seems clear that the courts have jurisdiction to hear challenges of this nature. Whether a temporary officer, not appointed un-

71 Id. at 550 .

72 See text at note 43 supra.

73 See text at note 44 supra.

74 The President might even be able to dismiss an officer who sought quo warranto against a temporary presidential appointee. But see Nader v. Bork, Civil No. 1954-73 (D.D.C., filed Nov. 14, 1973), in which the court held that Archibald Cox had been dismissed in violation of Justice Department regulations. See also note 5 supra.

75 See Williams v. Phillips, 360 F. Supp. 1363 (D.D.C. 1973).

$76 I d$. at 1366.

77476 F.2d 533 (D.C. Cir. 1973) (advance sheet) (opinion withdrawn by order of the court).

78 The court placed particular emphasis on the duties peculiar to the House, such as impeachment and origination of appropriations. $I d$. at 536 . 
der the recess vacancy clause or pursuant to statute, is properly in office is a controversy arising under the Constitution; a suit "arises under" the Constitution, and thus satisfies the jurisdictional requirement of article III, section 2, if a claim will be sustained if the Constitution is given one construction, but defeated if it is given another. ${ }^{78}$ An official might be legally in office if the Constitution grants a temporary appointment power in addition to that given by the recess vacancy clause or statute, but illegally in office if no such power exists.

A more serious obstacle to justiciability may be presented by the political question doctrine. Political questions are "not justiciable in the federal courts because of the separation of powers provided by the Constitution."so Only two of the elements of the political question doctrine enumerated by the Supreme Court in Baker $v$. Carr ${ }^{81}$ are arguably present in the senatorial challenge to a temporary appointment. First, if there is any "textually demonstrable constitutional commitment of the issue to a coordinate political department," 82 that commitment is made to the legislative branch. The senatorial challenge is brought to protect precisely that constitutional commitment. To argue that the courts should not consider the challenge because any challenge must come in the Congress might prevent members of the Senate from enforcing their rights in the manner they feel most appropriate. This position would be inconsistent with the underlying purpose of the political question doctrine. ${ }^{83}$ In addition, a case presents a nonjusticiable political question if there is "a lack of judicially discoverable and manageable standards of resolving it." 84 The stan-

79 Powell v. McCormack, 395 U.S. 486, 514 (1969); Bell v. Hood, 327 U.S. 678, 685 (1946).

80 Powell v. McCormack, 395 U.S. 486, 517 (1969).

81369 U.S. 186 (1962). The other elements are: "the impossibility of deciding without an initial policy determination of a kind clearly for nonjudicial discretion; or the impossibility of a court's undertaking independent resolution without expressing lack of the respect due coordinate branches of government; or an unusual need for unquestioning adherence to a political decision already made; or the potentiality of embarassment from multifarious pronouncements by various departments on one question." Id. at 217. Although the "multifarious pronouncements" criterion might seem to apply, the courts would be acting in an area in which their interpretations have long been regarded as definitive. See, e.g., Williams v. Phillips, 360 F. Supp. 1363 (D.D.C. 1973); United States v. Maurice, 26 F. Cas. 1211 (No. 15,747) (C.C.D. Va. 1823); cf. Miguel v. McCarl, 291 U.S. 442 (1932); Kendall v. United States ex rel. Stokes, 37 U.S. (12 Pet.) 524 (1838). The Supreme Court has also recognized its ability to make similar decisions involving issues of this kind. See, e.g., Powell v. McCormack, 395 U.S. 486 (1969). The other criteria are obviously inapplicable.

82369 U.S. at 217; see note 98 infra.

83 The existence of the writ of quo warranto at common law provides further evidence that this question has long been regarded as justiciable.

84369 U.S. at 217. 
dards by which the courts would decide a senatorial challenge are provided by the constitutional and statutory provisions on appointments; the courts have often made decisions concerning the President's authority to perform specific acts. ${ }^{85}$ Interpretation of the Constitution and statutes, including examination of the significance of constitutional history and congressional intent, is an essential judicial function.

Thus, a senatorial challenge to an appointment made by the President without the advice and consent of the Senate presents a justiciable question. If the court finds that a temporary appointment is unlawful, the result, as in Williams, would be a declaration that the official is serving improperly and an injunction against future action by that official.

\section{B. Indirect Challenges}

Although the remedies of quo warranto and direct senatorial challenge are unavailable to employees and beneficiaries of the relevant agency, the validity of specific acts by the appointee in question may be subject to challenge by such people. The issue raised is similar to that raised in the senatorial suit; the indirect challenge can allege injury caused by circumvention of procedures specified in the Constitution and federal statutes. One advantage of this indirect remedy is the facilitation of challenges to particular administrative actions. In challenging the validity of an appointment, the direct remedies might not reverse actions taken by the improper appointee.

1. Standing. The Supreme Court has held that the public interest in having the government administered according to law does not provide standing for all citizens to challenge the actions of government officials. ${ }^{86}$ The plaintiff must therefore challenge some particular actions that he or she has standing to attack and urge the invalidity of the appointment as a basis for relief. The Administrative Procedure Act provides that "any person adversely affected in fact by agency action or aggrieved within the meaning of any statute has standing to challenge administrative action." 87 In Association of Data Processing Service Organizations $v$. Camp,${ }^{88}$ the Supreme Court interpreted this provision to require plaintiffs to demonstrate both injury in fact and

85 See, e.g., Youngstown Sheet \& Tube Co. v. Sawyer, 343 U.S. 579 (1952); Miguel v. McCarl, 291 U.S. 442 (1934); Kendall v. United States ex rel. Stokes, 37 U.S. (12 Pet.) 524 (1838); Comment, Executive Impounding of Funds; The Judicial Response, $40 \mathrm{U}$. CHI.

L. REv. 328, 346 (1973).

88 Baker v. Carr, 369 U.S. 186, 208 (1962); Ex parte Levitt, 302 U.S. 633, 634 (1998).

875 U.S.C. \& 702 (1970).

88397 U.S. 150 (1970). 
an interest "arguably within the zone of interests to be protected or regulated by the statute or constitutional guarantee in question." 80

The Supreme Court held in Barlow $v$. Collins ${ }^{90}$ that, under the Data Processing standard, beneficiaries of an agency program had standing to contest administrative action that injured them. The court reasoned that these people were clearly within the zone of interests protected by the legislation setting up the program in question. ${ }^{.1}$ Even broader language was used in Peoples v. United States Department of Agriculture.92 The court there found "a presumptive standing, operative unless negatived by a statutory provision ... [in] those who were intended beneficiaries of the statutory provisions, even if they are not the primary beneficiaries of the statute."93 This language would clearly cover the Barlow situation and also embrace employees who receive the benefit of employment from the enactment involved. One court has specifically held that people who allege that they have been deprived of employment by administrative action have standing to challenge that action. ${ }^{9 *}$ Similarly, employees who were to be discharged during the dismantling of OEO by Acting Director Phillips were held to have standing to attack the validity of his action. ${ }^{95}$

As the Supreme Court explained in Sierra Club v. Morton, ${ }^{90}$ if "standing is established, the party may assert the interests of the general public in support of his claims for equitable relief." beneficiary or employee has obtained standing he or she may therefore assert the public interest in having temporary officers appointed as provided by the Constitution and statute, basing the right to relief on the invalidity of the appointment and the appointee's consequent lack of legal authority. ${ }^{98}$

$89 \mathrm{Id}$. at $152-53$. For a recent analysis of the problem of standing, see Scott, Standing in the Supreme Court-A Functional Analysis, 86 HARv. L. REv. 645 (1973).

90397 U.S. 159 (1970).

91 Id. at 167 .

92427 F.2d 561 (D.C. Cir. 1970).

$93 \mathrm{Id}$. at 563 .

94 Lodge 1858, AFGE v. Paine, 496 F.2d 882 (D.C. Cir. 1970).

95 Local 2677 v. Phillips, 358 F. Supp. 60 (D.D.C. 1973).

96405 U.S. 727 (1972).

97 Id. at 740n. 15 .

98 The political question doctrine may present a more serious problem for indirect challenges that it did for senatorial actions. See text and notes at notes 80-85 supra. Although the same argument against application of the "textually demonstrable constitutional commitment" criterion does not apply, it is not clear that there is a constitutional commitment of the issue of the validity of a temporary appointment to the legislative branch. Although the Congress is given authority to regulate the making of temporary appointments, it is not authorized to judge when its regulations have been violated. Thus, the political question doctrine is inapplicable. 
2. The De Facto Officer Doctrine. If a court were to find the challenged administrative action invalid on grounds other than the constitutional claim, the question of the validity of the temporary appointment would not be reached.99 If the action is not otherwise invalid, the common law de facto officer doctrine may prevent the court from considering whether an appointee is properly in office. This doctrine is based on a desire to promote the efficient functioning of the government by allowing the public to rely on actions taken by government officials with apparent authority and by protecting officers from distracting and frivolous attacks on their right to hold office. ${ }^{100}$ The doctrine validates the acts of an individual who is in office with a colorable claim of proper appointment.101 The authority of the official in question may not be collaterally attacked in an effort to procure relief from an action he or she has taken. ${ }^{102}$ Actions by an official who performs duties pursuant to an appointment that is invalid because of a defect in the appointment process have been judicially declared binding based on the de facto officer doctrine. ${ }^{103}$ Although this principle might validate actions by officials appointed by the President in excess of his authority, recent cases indicate that the doctrine might be inapplicable in these circumstances. ${ }^{104}$

99 In Local 2677 v. Phillips, 358 F. Supp. 60 (D.D.C. 1973), an employee suit challenging the attempt to dismantle OEO, the court held that the dismantling was invalid. Thus the court did not rule on the claim that the appointment was invalid. $C f$. Williams v. Phillips, 360 F. Supp. 1363, 1365 (D.D.C. 1973). It is generally irrelevant whether the administrative action complained of would ordinarily be reviewable or would be unreviewable because it is committed to the discretion of the officer. The claim for relief here considered is based not on the invalid nature of the action, but rather on the official's lack of authority to take any action at all.

100 Norton v. Shelby County, 118 U.S. 425, 411 (1886); United States ex rel. Doss v. Lindsley, 148 F.2d 22, 23 (7th Cir. 1945); United States ex rel. Watkins v. Pennsylvania, 214 F. Supp. 913, 916 (W.D. Pa. 1963).

101 State v. Carroll, 38 Conn. 449 (1871). "Of course, the acts of an officer, whether de facto or de jure, are open to attack when they exceed the power vested in the office de jure." Comment, The De Facto Officer Doctrine, 63 Colum. L. REv. 909, 912 (1963). Although the doctrine also applies to elective offices, that aspect of the doctrine is not relevant to the analysis of this comment.

102 McDowell v. United States, 159 U.S. 596, 601 (1895); In re Manning, 139 U.S. 504, 506 (1891); Norton v. Shelby County, 118 U.S. 425, 441 (1886); United States v. Nussbaum, 306 F. Supp. 66, 68 (N.D. Cal. 1969); People v. White, 24 Wend. 520, 525 (N.Y. Ct. Err. 1840). See also A. Constantineau, A Treatise on the De Facto Doctrine $\$ 429$ (1910); Pannam, Unconstitutional Statutes and De Facto Officers, 2 FED. L. REv. 37, 41 (1966).

103 E.g., State v. Carroll, 38 Conn. 449 (1871).

104 More traditional limitations on the applicability of the doctrine are unlikely to prevent its operation here. For example, the courts have long recognized that there can be no de facto officer where there is no de jure office. Norton v. Shelby County, 118 U.S. 425 (1886); Kempster v. City of Milwaukee, 97 Wis. 343,72 N.W. 743 (1897). It might be argued that Phillips could not have been a de facto officer, because the position to which he had 
In Glidden Co. v. Zdanok, ${ }^{105}$ decisions of two appellate judges were contested on the grounds that they allegedly were not legally authorized to decide the cases. The Supreme Court rejected the assertion that the judges' actions were protected from challenge by the de facto officer doctrine; "the alleged defect of authority here relates to basic constitutional protections designed in part for the protection of litigants." ${ }^{06}$ United States $v$. Allocco ${ }^{107}$ was a habeas corpus proceeding collaterally attacking a judgment rendered by a judge appointed during a recess of the Senate to a vacancy that had existed during the session. Citing Glidden the Second Circuit Court of Appeals held that the de facto officer doctrine could not be invoked because of the "strong interest of the federal judiciary in maintaining the constitutional plan of separation of powers."108

It is possible the courts could refuse to extend Glidden and Allocco to cases involving nonjudicial officers. The cases might also be read to create an exception to the doctrine only where the due process rights of litigants are asserted, or where a plaintiff alleges a violation of another personal constitutional guarantee. Any of these limited readings would prevent beneficiaries or employees from claiming that the cases create an applicable exception. A broader interpretation, however, as commentators have recognized, ${ }^{109}$ is suggested by $A l$ locco ${ }^{110}$ - that the doctrine will not prevent the litigation of a substantial constitutional question.

This comment proposes that the exception created by Glidden and Allocco should be applied where the President has made a temporary appointment while the Senate is in session and without statutory authorization or confirmation by the Senate. The courts should not lose sight of the fact that the basis of the de facto officer doctrine is merely

been appointed (Acting Director of OEO) had not been created by statute. See note 51 supra. This limitation, however, is illusory; it could easily have been avoided by designating Phillips to be Director temporarily. Although such an appointment would clearly not be valid until confirmed by the Senate, this designation might avoid the de jure office requirement of the de facto officer doctrine.

105370 U.S. 530 (1962). The allegations were that the judges were not appointed with life tenure and thus constitutionally not qualified to be federal judges. U.S. ConsT. art. III, $\S 1$.

106370 U.S. at 536.

107305 F.2d 704 (2d Cir. 1962). The facts here were analogous to Ex parte Ward, 173 U.S. 452 (1899), where the Supreme Court refused to permit review of the acts of a de facto judge.

108305 F.2d at 707.

109 Pannam, supra note 102, at 62-63; Note, 38 N.Y.U.X. REv. 169, 173 (1963); cf. Comment, 111 U. PA. L. REv. 364, 365 (1963).

$110305 \mathrm{~F} .2 \mathrm{~d}$ at 707. 
the public interest in the smooth functioning of the government. ${ }^{111}$ Although public policy dictates prevention of frivolous title challenges, the de facto officer doctrine should not be allowed to stand in the way of enforcement of a constitutional duty.

\section{Conclusion}

The Constitution provides that the appointment power of the President is to be exercised subject to the advice and consent of the Senate except when the President acts with specific congressional authorization or when the Senate is in recess. If the President attempts to make an unconfirmed appointment under any other circumstances, for example by designating the appointment "temporary," there are several methods to challenge his action. The executive branch can seek a writ of quo warranto to remove the appointee, although it is unlikely to do so. Members of the Senate can sue to have the appointee enjoined from continuing to act as an officer. In no other case may a direct challenge be brought to contest the validity of the appointment.

Employees or beneficiaries of the office in question might indirectly challenge the title of the official by attacking particular actions on the ground of a lack of authority. Such suits, however, might be frustrated by the de facto officer doctrine. Since direct challenges by the executive branch or members of the Senate are rare, and because specific actions can be attacked only through indirect challenges by employees or beneficiaries, it is urged that the Glidden and Allocco exception to the de facto officer doctrine be applied in this situation. Only by recognizing that violation of the constitutional appointment requirements presents a serious constitutional question, and therefore limiting the de facto officer doctrine to deny its applicability in such cases, can we be certain that the government will function according to the constitutionally mandated separation and balance of power.

\section{Lois Reznick}

111 Pannam, supra note 102, at 59: "Even at common law the de facto doctrine yielded when there were policies involved which outweighed public inconvenience and the frustration of legitimate reliance which are the foundation of the doctrine. It would be surprising if there were not some basic policies reflected in a constitutional document which overcame certain claims to de facto status. There is a tension between a constitutional provision which invalidates an act and a common law doctrine which gives it limited validity. This tension cannot be ignored by an automatic application of the de facto officer doctrine any more than it can be by the automatic refusal to apply it in those cases." 